\title{
The Impact of the Volatility of the US Government Bonds Rate on the Islamic Index Return
}

\author{
Irfan DJEDOVIĆ* , Ugur ERGUN ${ }^{* *}$
}

Received: December 19, 2017

Revised: April 6, 2018

Accepted: May 12, 2018.

\begin{abstract}
This study investigates the impact of the US monetary policy, represented through the volatility of the US government bonds rate, on the return of Dow Jones UK Islamic index. Monthly observations spans, in the period between December 2006 and June 2017, are obtained from the International Monetary Fund database. The OLS regression and granger causality analysis are used to investigate the impact. The results of the analysis show that there is significant impact of the US monetary policy on the Dow Jones UK Islamic index return.
\end{abstract}

Keywords: Islamic stock market index, US Government bonds, volatility, return.

JEL Code Classification: G1

UDC: 336.763 .33

DOI: https://doi.org/10.17015/ejbe.2018.021.05

\footnotetext{
* Corresponding Author. PhD Candidate, International Burch University, Bosnia and Herzegovina, E-mail: irfan_djedovic@hotmail.com

Associate Professor, Epoka University, Tirana, Albania. E-mail: uergun@epoka.edu.al 


\section{Introduction}

Islamic financial markets and their financial potential is having high growth rates since the recent world financial crisis. Even though the portion of Islamic financial markets money potential takes only a small proportion out of total world financial markets money mass, Islamic finance is becoming more and more attractive because it appears as an alternative to the conventional financial markets.

Due to the huge financial potential of the investors coming from the Muslim countries, and their desire to invest in accordance with Sharia - Islamic law, many Islamic stock market indices were formed in Muslim countries, and also most of the major western stock market indices have included option of Islamic stock market indices, as a counterpart to the existing ones. This means that all the financial institutions that included Islamic stock market indices in their portfolio, had to follow the strict rules and screening methodology, in order to filter existing conventional indices.

Based on their great potential of growth and profitability, Islamic stock market indices have gained popularity worldwide. These indices attract international capital flows from both Muslim and non-Muslim investors. That made global index providers more dedicated to offer Islamic indices, since Islamic investors were showing greater selectivity in their investment choices. Another advantage that Islamic indices offer is that investment in global capital market could benefit from diversification alternatives in both conventional and Islamic indices, since Islamic stock market indices are establishing themselves as an important diversification tool to investors. Therefore, most of the investors find the investment in various indices, including Islamic ones, as one of the ways of diversification.

Some of the most important Islamic indices are the following: Financial Times Islamic Index Series (FTSE), Dow Jones Islamic Market Index (DJIM), Standard \& Poor Shariah Index (S\&P), and Morgan Stanley Capital International Islamic Index (MSCl).

Therefore, the research that investigates Islamic indices' behavior is very important nowadays, due to its higher importance and popularity, as well as the need for a deeper investigation of this financial sector, since the literature covering these issues is still developing. This type of research could be beneficial for the academic society as well as for the investors.

In this study, the focus is on the return (behavior) of the Islamic stock market index. To narrow it down even further, the focal point of the research is Islamic stock market index in UK. This study examines one of the potential factors that affect Dow Jones UK Islamic index return, namely, the US Federal Reserve's policy, represented through US Government bonds rate.

This research emphasizes that it is widely believed that the stock market is sensitive to macroeconomic news. Therefore, market participants tend to follow 
closely the government releases of economic data and announcements of monetary policy changes. These types of surprises move stock prices up or down, or so is suggested by the financial press.

As Yusof and Majid (2007) state, the interaction between stock market volatility and macroeconomic variables has been extensively researched in the financial economics literature. Among the most pertinent questions raised are the following:

1. To what extent the explanatory power of monetary policy variables is able to explain the stock market volatility?

2. What is the extent to which the volatility in the international monetary policy is transmitted across national stock markets?

Although, the academic writing on the relationship between macroeconomic variables and stock market returns has been extensively researched, there is a certain gap in the literature pertaining to the relationship between macroeconomic variables and Sharia indices, which are becoming an interesting area of research due to a fast-growing force of the Islamic finance.

Since the literature investigating the behavior of the Islamic stock market indices is still developing, it is important to investigate whether there is an international macroeconomic impact on the Islamic stock market index return/ behavior in UK. Therefore, the return of the Islamic index is investigated based on the US Government bonds rate, as a measure for the international interest rate.

The results from this study suggest that there is significant impact coming from US Federal Reserve's monetary policy, represented through the volatility of US Government bonds rate on the return rate of the Islamic index in the UK, namely Dow Jones UK Islamic index.

To put it succinctly, there are several reasons to investigate the relation between the Dow Jones UK Islamic index return and US Government bonds rate.

It is widely believed that the stock market is sensitive to macroeconomic news. Therefore, market participants tend to follow closely government releases of economic data and announcements of monetary policy changes. This type of surprises moves stock prices up or down. Based on this, it is important to investigate whether there is an international macroeconomic impact on the Islamic stock market index behavior. In line with this argument Yusof and Majid (2007) state that among the most pertinent questions rose is the question of the extent to which the volatility in the international monetary policy is transmitted across national stock markets.

Many previous studies investigated the impact of the international globalization and increased capital market integration. The majority of this work has concluded that the USA is the world's dominant economy, and as a result, research has generally found that US stock markets are exogenous and lead other world markets 
(Arshanapalli, Doukas, \& Lang, 1995; Masih \& Masih, 1999). Therefore, in addition to investigating the behavior of Islamic stock market, several studies include US Government bonds rate or US Federal Funds Rate as a measure for international interest rate, in order to capture the international influence (Yusof \& Majid, 2007; Majid \& Yusof, 2009; Ajmi, Hammoudeh, Nguyen, \& Sarafrazi, 2014). Thus, this study uses US Government Bonds rate as an external world dominant macroeconomic factor to investigate the external effect on the Islamic index in UK.

\section{Literature Review}

In previous studies, the interaction of share returns, and macroeconomic variables has been a subject of interest among academics and practitioners. This type of studies has shown the existence of a significant relationship between stock markets with certain macroeconomic variables in various countries.

In overall, these studies could be divided into two major categories. As Rahman, Sidek, and Tafri (2009) suggest, the first category are studies that determine the factors affecting stock prices such as Sadorsky (2003), Ibrahim and Aziz (2003), Chen (2003), Mavrides (2000) and Lee (1992), while the second category of studies examines factors determining stock return volatility such as Beltratti and Morana (2006) and Schwert (1989). The former focuses on the stock return, while the latter is concerned with the volatility of the stock itself.

While the association between the stock market and economic activities is quite obvious regardless of its causality direction, a standardized set of macroeconomic variables is not found. Macroeconomic variables selected to examine the determinants of the stock market tend to be slightly different in various studies.

However, Rahman et al. (2009) suggests that the rate of inflation, money growth, interest rates, industrial production, reserves, and exchange rates are the most popular significant factors in explaining the stock market movement.

In the following paragraphs we will mention some of the studies that were investigating these issues, including both the issue of stock return as well as the issue of the volatility of stocks, affected by the macroeconomic variables with the focus on the interest rate.

Talla (2013), Pathan and Masih (2013), Patel (2012), Sariannidis et al. (2010), Rahman et al. (2009), Li and Zuliu (1998), Samitas and Kenourgios (2007), Elyasiani and Mansur (1998), and Chen, Roll and Ross (1986) explored the impact of economic variables on stock returns, and their influence on the asset price. Furthermore, Islam (2003) investigated the relationship between macroeconomic indicators (interest rate, inflation rate, exchange rate and the industrial productivity) and the Kuala Lumpur Stock Exchange (KLSE) Composite Index. Günsel and Çukur (2007) investigated seven macroeconomic variables on London Stock Returns. Schwert (1989) conducted an extensive array of tests on the macroeconomic causes of stock market volatility over long runs of monthly data for 
the United States. Liljeblom and Stenius (1997), Kearney and Daly (1998), and Muradoglu, Metin, and Berument (1999) provided further evidence on the macroeconomic causes of the stock market volatility.

While the studies on the conventional stock market are proliferating in the recent decades, less attention is being given to its Islamic counterpart. In the following paragraphs mentioned are the studies that focus on Islamic stock indices.

However, these studies investigating the relationship between Islamic indices return and volatility, and macroeconomic factors, and their impact on Islamic indices, are still rare.

Yusof and Majid (2007) attempt to explore the extent to which the conditional volatilities of both conventional and Islamic stock markets in Malaysia are related to the conditional volatility of monetary policy variables. They tested monetary policy variables including domestic interest rates (TBR). Furthermore, besides domestic monetary variables, the authors included in their study a foreign interest rate, namely US Federal Funds Rate (FFR), in order to capture international influence on both stock markets. On the other hand, the Kuala Lumpur Composite Index (KLCl) and Rashid Hussain Berhad Islamic Index (RHBII) are used as measures for conventional and Islamic stock markets, respectively. The results of the study show that interest rate volatility affects the conventional stock market volatility, but not the Islamic stock market volatility. This highlights the tenet of Islamic principles that the interest rate is not a significant variable in explaining the stock market volatility.

Majid and Yusof (2009) investigated the long-run relationship between Islamic capital markets in Malaysia and major macroeconomic variables (i.e., money supply, exchange rates, interest rates, the industrial production index, and the Federal funds rate) using the autoregressive distributed lag (ARDL) model. Their results show that exchange rates, money supply, interest rates and the Federal funds rate significantly affect KLSI, suggesting that these variables might be suitable targets for the government to focus on in order to stabilize the Islamic stock market and to encourage more capital inflows into the market.

In his study, Albaity (2011) investigated the effects of changes in monetary policy, interest rate and the rate of inflation on the Islamic stock market indices in Malaysia and the US, as well as the effects on the non-Islamic stock market indices. The study also examines the impact of volatilities of the monetary variables, interest rates, and the inflation rate on two Islamic stock market indices. The results show that in the multivariate model, the Islamic stock market index in the US (DJIMI) is influenced by the interest rate and the inflation rate in the mean and variance equations.

In the study of Hussin et al. (2012), the relationship between the Kuala Lumpur Syariah Index (KLSI) and a set of five macroeconomic variables are examined. They found that Islamic share prices (KLSI) have a positive relationship with the 
economic growth rate (IPI) and inflation (CPI), but that they have a negative relationship with money supply (M3), the Islamic investment rate (IIR) and the foreign exchange rate (MYR). All these variables, except the Islamic Investment Rate (IIR), show a significant relationship with Islamic share prices. Furthermore, the long-term relationship between the Islamic investment rate (IIR), which served as a substitute for the conventional interest rate and Islamic share prices (KLSI), did not show a significant relationship.

Vejzagic and Zarafat (2013) examined the long-term equilibrium relationships between selected macroeconomic variables and the FTSE Bursa Malaysia Hijrah Shariah Index. More precisely, the study examined the impact of the Islamic index on macroeconomic variables in Malaysia. It showed that the FTSE Bursa Malaysia Hijrah Shariah Index plays an important role in economy, as it influences and initiates major macroeconomic variables such as interest rates, money supply, consumer price index, and exchange rate. It statistically shows a significant relationship with interest rates, exchange rates and money supply; it negatively affects interest rates and exchange rates, while money supply is affected positively in the case of disequilibrium.

In his research, Shamsuddin (2014) found that the aggregate portfolio of the Dow Jones Islamic stocks is immune to both the change in the interest rate and the volatility of the interest rate. Thus, the shariah-screening criteria introduced by Dow Jones eliminate the interest risk exposures of a well-diversified Islamic equity portfolio. However, the study found evidence of both positive and negative sensitivity of some DJ Islamic sector portfolios to interest rates. In general, the evidence of interest rate risk exposure is less pronounced among the DJ Islamic sector portfolios than that of their mainstream counterparts-the Dow Jones World sector indices.

In their recent research, Ajmi et al. (2014) use linear Granger causality and nonlinear Granger causality tests to investigate the possible links between the Islamic and global conventional stock markets, and between the Islamic stock market and several global economic and financial shocks. They found a significant linkage between the Islamic stock market and interest rates and interest-bearing securities, which should be inconsistent with the Sharia rules.

Furthermore, Rana and Akhter (2015) investigated the extent to which the conditional volatilities of both the Sharia compliant stock and the conventional stock are related to those of interest rates and exchange rates in the emerging economy of Pakistan. The findings show a positive and statistically significant effect of interest rate volatility on $\mathrm{KSE}-100$, whereas $\mathrm{KMI}-30$ remains unaffected by the same.

As an overall summary of the previous studies regarding volatility of interest rates, as well as the volatility of US Federal Funds Rate and their impact on the Islamic stock market return, it can be stated that the results are not uniform. Some studies 
including Yusof and Majid (2007), Hussin et al. (2012), Shamsuddin (2014) and Rana and Akhter (2015) find no significant impact of interest rate volatility or US Federal Funds Rate volatility on Islamic stock prices.

However, other studies including Majid and Yusof (2009), Albaity (2011), Vejzagic and Zarafat (2013), Shamsuddin (2014), and Ajmi et al. (2014) find significant impact of interest rates volatility or US Federal Funds Rate volatility on the Islamic stock prices.

Speaking about Dow Jones Indices in general, there is evidence that interest rate risk exposure is less pronounced among the DJ Islamic sector portfolios than that of their mainstream counterparts - the Dow Jones World sector indices.

\section{Data and Methodology}

This section describes the data and empirical methods used to investigate the relationship between the selected variables. In this study, the Dow Jones UK Islamic Index return was selected as the dependent variable, whereas the volatility of the US Government bonds rate was selected as the independent variable.

Monthly observations of these two variables span the period between December 2006 and June 2017 and were obtained from the International Monetary Fund database. The least squares method (regression analysis) was used to investigate the impact.

The arithmetic return of the Islamic index time series is estimated by subtracting the index value at time $t-1$ from the index value at time $t$ and dividing it by the index value at time $t$ as shown in Eq. (1), where $R_{t}$ is the return at time $t, P_{t}$ is the index at time $t$ and $P_{t-1}$ is the index at time $t-1$.

$$
R_{t}=\left(P_{t}-P_{t^{-1}}\right) / P_{t^{-1}}
$$

Before the volatility of the US Government bonds time series is estimated, the growth rate of the US Government bonds is estimated by subtracting the bonds value at time $t-1$ from the bonds value at time $t$ and dividing it by the bonds value at time $t$ as shown in Eq. (2), where $G_{t}$ is the growth rate at time $t, B_{t}$ is the bond rate at time $t$ and $B_{t-1}$ is the bond rate at time $t-1$.

$$
G_{t}=\left(B_{t}-B_{t-1}\right) / B_{t-1}
$$

The next step was the estimation of the volatility of the US government bonds rate. Volatility is measured as the square of the deviations from the mean. We consider that $\Delta \boldsymbol{y}_{\boldsymbol{t}}$ indicate the series with deviations from means.

As it can be seen from Equation 3, the volatility of the US Government bonds rate is estimated as:

$$
\begin{aligned}
\Delta \boldsymbol{y}_{t}^{2} & =\left(\Delta \boldsymbol{y}_{t}-\Delta \overline{\boldsymbol{y}}\right)^{2} \\
& \text { where } \Delta \bar{y}=\Sigma \Delta y_{t} / T .
\end{aligned}
$$


Irfan DJEDOVIĆ \& Ugur ERGUN

\section{Empirical Analysis and Results}

In this section, unit root tests for the two-time series, and the results of the OLS regression and Granger causality analysis, are presented. We highlight the impact of the volatility of the US government bonds rate on the Islamic index return rate.

\subsection{Unit Root Results}

From the Augmented Dickey-Fuller and Phillips-Perron unit root tests results given in Table 1, we can see that three variables used in the study are stationary at the levels.

Table 1. Results of Unit Root test for variables

\begin{tabular}{lcc}
\hline & ADF (Test Statistics) & PP (Test Statistics) \\
\hline Variables & Level & Level \\
\hline DJ_UK_RETURN & $0.0000^{*}$ & $0.0000^{*}$ \\
US_GOVERNM_BONDS & $0.0000^{*}$ & $0.0000^{*}$ \\
VFED & $0.0000^{*}$ & $0.0000^{*}$ \\
\hline
\end{tabular}

Note: ${ }^{*}$ indicates significance at the $1 \%$.

\subsection{Results}

In this section the results of the empirical analysis are presented. The volatility of the US Government bonds rate is the independent variable used to investigate the potential impact on the return rate of the Dow Jones United Kingdom Islamic Index (dependent variable).

Empirical results summarized in Table 2 indicate that the volatility of US Government bonds rate (VFED) has significant impact on the Dow Jones UK Islamic Index (DJUKI) return. The given model satisfies serial correlation and heteroskedasticity assumptions (see Appendix A and Appendix B). In order to strengthen the results of the empirical model employed in the OLS regression (Table 2), current study attempts to check for granger-causality between volatility of the US Government bonds rate (VFED) and the return of Dow Jones UK Islamic Index (DJUKI).

Table 2. Results of OLS Regression

\begin{tabular}{|c|c|c|c|c|}
\hline Dependent variable & DJ_UK_RET & \multicolumn{2}{|c|}{ Number of observation } & 118 \\
\hline Mean dependent var. & 0.001182 & \multicolumn{2}{|c|}{ Number of variables } & 2 \\
\hline S.D dependent var. & 0.055073 & \multicolumn{2}{|c|}{ R-squared } & 0.032046 \\
\hline F-statistics & 3.972811 & \multicolumn{2}{|c|}{ Adjusted R-squared } & 0.023980 \\
\hline Prob (F-statistics) & 0.048509 & \multicolumn{2}{|c|}{ Sum square residuals } & 0.355238 \\
\hline Log likelihood & 183.0678 & \multicolumn{2}{|c|}{ S.E. of regression } & 0.054409 \\
\hline Akaike info criterion & -2.968324 & \multicolumn{2}{|c|}{ Hannan-Quinn Criterion } & -2.949654 \\
\hline Schwarz criterion & -2.922357 & \multicolumn{2}{|c|}{ Durbin-Watson stat } & 2.065142 \\
\hline Variable & Coefficient & Std.Error & t-Statistics & Probability \\
\hline VFED & 0.802612 & 0.402677 & 1.993191 & 0.0485 \\
\hline $\mathrm{C}$ & -0.003911 & 0.005549 & -0.704848 & 0.4823 \\
\hline
\end{tabular}


In Table 3 granger causality tests' results are presented. Granger causality analysis revealed that there is uni-directional causal relationship between volatility of the US Government bonds rate (VFED) and the return of Dow Jones UK Islamic Index (DJUKI). Thus, VFED can be said to granger cause DJUKI return.

Table 3. Pairwise Granger Causality Test

\begin{tabular}{lccc}
\hline Null Hypothesis: & Obs & F-Statistic & Prob. \\
\hline VFED does not Granger Cause DJ_UK_ISL_RET & 120 & 4.73607 & $0.0106^{*}$ \\
\hline DJ_UK_ISL_RET does not Granger Cause VFED & & 1.11437 & 0.3316 \\
\hline
\end{tabular}

Note: * indicates significance at the $5 \%$.

These results are in line with the study of Majid and Yusof (2009). Their study reveals that both changes in the local monetary policy variables and in the US monetary policy as measured by the changes in the FFR have a significant direct impact on the Islamic stock market index in Malaysia. They find a significant longterm relationship between Federal Funds Rate (FFR) and Kuala Lumpur Shariah Index (KLSI). Also, Albaity (2011) finds that the Dow Jones Islamic index in USA (DJIMI) is influenced by the interest rate in terms of the mean and variance equation. Furthermore, the study of Shamsuddin (2014) finds this relationship in some sectoral indices. Ajmi et al. (2014) use the heteroscedasticity-robust linear Granger causality and nonlinear Granger causality tests to examine the links between the Islamic and global conventional stock markets and between the Islamic stock market and several global economic and financial shocks. They show a connection between the Islamic stock market and interest rates.

However, the results are not in line with the results of Mohd and Yusof (2007) who do not find a significant relationship between Federal Funds Rate (FFR) and Malaysian Islamic stock market volatility. Hakim and Rashidian (2005) and Yusof and Majid (2006) found that interest rate does not have any impact on the Islamic stock market index in US and Malaysia respectively. Also, Hussin et al. (2012) did not determine a significant relationship between the Kuala Lumpur Shariah Index (KLSI) and the Islamic investment rate (IIR) which was a substitute for the conventional interest rate. Furthermore, Albaity (2011) did not find any significant relationship between the domestic interest rate and the variance of Islamic indices KLSI and the DJMI variance. Shamsuddin (2014) does not find a significant relationship between the portfolio of the Dow Jones Islamic stocks and interest rates (US 10-year Treasury bond yields and US 3-month Treasury bill rates).

\section{Conclusion}

This study investigates the impact of the volatility of US Government bonds rate on the return of the Dow Jones United Kingdom Islamic Index using a monthly series of data from 2006 to 2017. 
The contributes to the existing knowledge on Islamic capital markets behavior and fills in the gap of the still developing amount of information regarding the international risk exposure of the Islamic stock market indices.

The ADF and PP unit root test, the OLS regression and granger causality analysis were used in this study. The unit root test results indicate that the variables are stationary at the level. The result of the OLS regression analysis indicates that the volatility of the US Government bonds rate has significant impact on the return rate of the Dow Jones United Kingdom Islamic Index. Furthermore, Granger causality analysis revealed that there is uni-directional causal relationship between volatility of the US Government bonds rate (VFED) and the return of Dow Jones UK Islamic Index (DJUKI), meaning that VFED granger causes DJUKI return.

The findings of the study indicate several important conclusions. First of all, the result, showing significant relationship between the international interest rate, represented through the US Government bonds rate and the Islamic index behavior in the United Kingdom, is not in line with the tenet of the Islamic finance principles which state that the interest rate (US Government bonds rate) is not a significant variable in explaining Islamic stock market volatility. This suggests that the Islamic stock market index in the UK is not immune to the change of the international interest rate volatility. So, it can be concluded that international interest risk exposures are not eliminated by the shariah screening process.

Secondly, these results are beneficial for the investors, who are searching for possibilities of diversification in their investment strategy. Results of previous studies show evidence that, in general, interest rate risk exposure is less pronounced among the DJ Islamic sector portfolios than that of their mainstream counterparts-the DJ World sector indices. However, in this study we find the exposure of Dow Jones UK Islamic index to the international interest rate. So, this finding suggests that the Islamic stock market in the UK is not immune to the US Federal Reserve's monetary policy changes - more precisely to the US Government bonds rate - which can be useful information while selecting stocks to invest in. Therefore, speaking from the investors' perspective, it can be concluded that investors cannot immunize their portfolios to international interest rate risks by investing in the Dow Jones UK Islamic index.

Therefore, it can be concluded that the results of this paper are relevant and valuable for both investors and financial analysts and provide new insights about the impact of volatility of the US Government bonds rate on the Islamic stock market return across market regimes.

Another conclusion is that while the international macroeconomic impact, represented through the US Government bonds rate, on the Islamic stock market index behavior in the UK is significant, it suggests that this market is not immune to some eventual global economic and financial shocks. So, one of the conclusions is 
The impact of the volatility of the US government bonds rate on the Islamic index return

that the volatility in the international monetary policy is transmitted across national stock markets in this certain case.

However, this study is not free from limitations. In this study, which focuses on Dow Jones Islamic Index in UK, only the interest rate impact coming from the United States is used. Future studies should include domestic interest rates, as well as some other international interest rates, in order to get a better picture of the behavior of the Islamic index in UK, as well as potential influences from other directions. Then the investors and financial analysts would have more precise information regarding their investment decisions. Therefore, further research work is essential to update the findings of this study.

\section{References}

Abdullah, D. A. \& Hayworth, S. C. (1993). Macroeconometrics of Stock Price Fluctuations. Quarterly Journal of Business and Economics 32(1), 49-63.

Ajmi, A. N., Hammoudeh, S., Nguyen, D., \& Sarafrazi, S. (2014). How strong are the causal relationships between Islamic stock markets and conventional financial systems? Evidence from linear and nonlinear tests. Journal of International Financial Markets, Institutions \& Money 28, 213-227. https://doi.org/10.1016/j.intfin.2013.11.004

Albaity, M.S., (2011). Impact of the Monetary Policy Instruments on Islamic Stock Market Index Return. Discussion Paper No. 2011-26| July 18, 2011. http://www.economicsejournal.org/economics/discussionpapers/2011-26

Arshanapalli, B., Doukas, J. \& Lang, L. (1995). Pre and post-October 1987 stock market linkages between U.S. and Asian markets. Pacific-Basin Finance Journal 3, 57-73.

Beltratti, A. \& Morana, C., (2006). Break and Persistency: Macroeconomic Causes of Stock Market Volatility. Journal of Econometrics 131(1-2), 151-177. https://doi.org/10.1016/i.jeconom.2005.01.007

Chen, M.H. (2003). Risk and Return: CAPM and CCAPM. The Quarterly Review of Economics and Finance 43(2), 369-393.

Chen, S.J., Roll, F. \& Ross, S.A. (1986). Economic Forces and the Stock Market. Journal of Business 59(3), 505-523. https://doi.org/10.1086/296344

Elyasiani, E. \& Mansur, I. (1998). Sensitivity of bank stock returns distribution to changes in the level of volatility of interest rate: a GARCH-M model. Journal of Banking and Finance 22(5), 535-63. https://doi.org/10.1016/S0378-4266(98)00003-X

Günsel, N. \& Çukur, S. (2007). The Effects of Macroeconomic Factors on the London Stock Returns: A Sectoral Approach. International Research Journal of Finance and Economics 10, 140-152.

Hakim, S. \& Rashidian, M. (2005). Risk and returns of Islamic stock market indexes, In 9th Economic Research Forum Annual Conference in Sharjah, UAE (pp. 26-28).

Hussin, M. Y. M., Muhammad, F., Abu, M. F., \& Awang, S. A. (2012). Macroeconomic Variables and Malaysian Islamic Stock Market: A Time Series Analysis. Journal of Business Studies Quarterly 3(4), 1-13. 


\section{Irfan DJEDOVIĆ \& Ugur ERGUN}

Ibrahim, M.H. \& Aziz, H. (2003). Macroeconomic variables and the Malaysian equity market: A view through rolling subsamples. Journal of Economic Studies 30(1), 6-27. https://doi.org/10.1108/01443580310455241

Islam, M. (2003). "The Kuala Lumpur stock market and economic factors: a general-tospecific error correction modeling test", Journal of the Academy of Business and Economics 1(1), 37-47.

Kearney, C., \& Daly, K. (1998). The causes of stock market volatility in Australia. Applied Financial Economics, 8(6), 597-605.

Lee, B. (1992). Causal Relations among Stock Returns, Interest Rates, Real Activity and Inflation. Journal of Finance 47, 1591-1603. https://doi.org/10.1111/j.15406261.1992.tb04673.x

Li, Li. \& Zuliu, F. H. (1998). "Responses of the Stock Market to Macroeconomic Announcements Across Economic States", Working Paper of the International Monetary Fund. https://ssrn.com/abstract $=882366$

Liljeblom, E., \& Stenius, M. (1997). Macroeconomic volatility and stock market volatility: empirical evidence on Finnish data. Applied financial economics, 7(4), 419-426.

Majid, M. S., \& Yusof, R. (2009). Long-run relationship between Islamic stock returns and macroeconomic variables: An application of the autoregressive distributed lag model. Humanomics 25(2), 127-141. https://doi.org/10.1108/08288660910964193.

Masih, A. \& Masih, R. (1999). 'Are Asian stock market fluctuations due mainly to intraregional contagion effects?', Pacific-Basin Finance Journal 7, 251-282.

Mavrides, M. (2000). Granger Causality Tests of Stock Returns: The U.S. and Japanese Stock Markets. Managerial Finance 26(12), 13-25.

Maysami, R.C. \& Koh, T.S. (2000), A Vector Error Correction model of the Singapore stock market. International Review of Economics and Finance 9(1), 79-96. https://doi.org/10.1016/S1059-0560(99)00042-8

Maysami, R.C., Howe, L.C. \& Hamzah, M.A. (2004). Relationship between Macroeconomic Variables and Stock Market Indices: Cointegration Evidence from Stock Exchange of Singapores: All-S sector Indices. Jurnal Pengurusan, 24, 47-77.

Mukherjee, T.K. \& Naka, A. (1995), “Dynamic Relationship between Macroeconomic Variables and The Japanese Stock Market: An Application of a Vector Error Correction Model", The Journal of Financial Research 18(2), 223-237.

Muradoglu, G., Metin, K., \& Berument, H. (1999). Financial Crisis and Changes in Determinants of Risk and Return: An Empirical Investigation of an Emerging Market (ISE). Multinational Finance Journal 3, 223-252.

Pathan, R. \& Masih, M., (2013). Relationship between macroeconomic variables and stock market index: evidence from India. Online at http://mpra.ub.uni-muenchen.de/63302/, MPRA Paper No. 63302, posted March 28, 2015.

Patel, S. (2012). The effect of Macroeconomic Determinants on the Performance of the Indian Stock Market. NMIMS Management Review, (22):117-127.

Rahman, A. A., Sidek, N. Z. M., \& Tafri, F. H. (2009). Macroeconomic determinants of Malaysian stock market. African Journal of Business Management 3(3), 95-106. 
The impact of the volatility of the US government bonds rate on the Islamic index return

Rana, M.E., \& Akhter, W. (2015). Performance of Islamic and conventional stock indices: empirical evidence from an emerging economy, Financial Innovation 1(1), 1:15.

Sadorsky, P. (2003). The Macroeconomic Determinants of Technology Stock Price Volatility. Review of Financial Economics 12, 191-205. https://doi.org/10.1016/S1058-3300(02)00071-X

Samitas, A. \& Kenourgios, D. (2007). Macroeconomic Factors' Influence on 'New' European Countries' Stock Returns: The Case of Four Transition Economies. International Journal of Financial Services Management 2, 34-49.

Sariannidis, N., Giannarakis, G., Litinas, N., \& Konteos, G. (2010). A GARCH Examination of Macroeconomic Effects on U.S. Stock Market: A Distinction Between the Total Market Index and the Sustainability Index. European Research Studies 8(1).

Schwert, G.W. (1989). Why does stock market volatility change over time? The Journal of Finance 44(5). https://doi.org/10.1111/j.1540-6261.1989.tb02647.x

Shamsuddin, A. (2014). Are Dow Jones Islamic equity indices exposed to interest rate risk?. Economic Modelling, 39, 273-281.

Talla, J.T., (2013). Impact of Macroeconomic Variables on the Stock Market Prices of the Stockholm Stock Exchange (OMXS30). Jönköping international business school, May 2013.

Vejzagic, M. and Zarafat, H., (2013). Relationship between macroeconomic variables and stock market index: Co-integration evidence from FTSE Bursa Malaysia hijrah shariah index. Asian journal of management sciences \& education 2(4).

Yusof, R. \& Majid, M.S. (2006). Policy and Persistence of Stock Returns Volatility: Conventional versus Islamic Stock Market. Journal of International Business and Entrepreneurship 12(1), 49-68.

Yusof, R. M., \& Majid, M. S. A. (2007). Stock market volatility transmission in Malaysia: Islamic versus conventional stock market. Journal of King Abdulaziz University: Islamic Economic 20(2), 17-35.

\section{Appendix A}

Table A1. Serial Correlation test result (Breusch-Godfrey Serial Correlation LM Test)

\begin{tabular}{llll}
\hline F-statistic & 0.487842 & Prob. F(2,118) & 0.6152 \\
Obs*R-squared & 1.000485 & Prob. Chi-Square(2) & 0.6064 \\
\hline
\end{tabular}


Irfan DJEDOVIĆ \& Ugur ERGUN

Table A2. Serial Correlation test result (OLS)

\begin{tabular}{|c|c|c|c|}
\hline Dependent variable & RESID & Number of observations & 122 \\
\hline Mean dependent var & $-2.28 \mathrm{E}-19$ & Number of variables & 4 \\
\hline S.D dependent var & 0.054183 & R-squared & 0.008201 \\
\hline F-statistics & 0.325228 & Adjusted R-squared & -0.017015 \\
\hline Prob(F-statistics) & 0.807114 & Sum squared residuals & 0.352325 \\
\hline Log likelihood & 183.5701 & S.E. of regression & 0.054643 \\
\hline Akaike info criterion & -2.943772 & Hannan-Quinn Criterion & -2.906431 \\
\hline Schwarz criterion & -2.851837 & Durbin-Watson stat & 2.013357 \\
\hline Variable & Coefficient & Std.Error t-Statistics & Probability \\
\hline Constant & 0.000103 & $0.005585 \quad 0.018500$ & 0.9853 \\
\hline VFED & -0.010679 & $0.408252 \quad-0.026157$ & 0.9792 \\
\hline RESID(-1) & -0.030572 & $0.092427-0.330766$ & 0.7414 \\
\hline $\operatorname{RESID}(-2)$ & 0.084965 & $0.092599 \quad 0.917560$ & 0.3607 \\
\hline
\end{tabular}

Probability value which is greater than 0.05 indicates that there is no serial correlations.

\section{Appendix B}

Table B1. Heteroskedasticity test result (Breusch-Pagan-Godfrey)

\begin{tabular}{llll}
\hline F-statistic & $\mathbf{1 . 6 2 0 8 8 8}$ & Prob. F(1,120) & $\mathbf{0 . 2 0 5 4}$ \\
Obs*R-squared & 1.625940 & Prob. Chi-Square(1) & $\mathbf{0 . 2 0 2 3}$ \\
Scaled explained SS & 2.138429 & Prob. Chi-Square(1) & $\mathbf{0 . 1 4 3 6}$ \\
\hline
\end{tabular}

\section{Table B2. Heteroskedasticity test result (OLS)}

\begin{tabular}{|c|c|c|c|c|}
\hline Dependent variable & $\mathrm{RESID}^{\wedge} 2$ & \multicolumn{2}{|c|}{ Number of observations } & 122 \\
\hline Mean dependent var & 0.002912 & \multicolumn{2}{|c|}{ Number of variables } & 2 \\
\hline S.D dependent var & 0.004821 & \multicolumn{2}{|c|}{ R-squared } & 0.013327 \\
\hline F-statistics & 1.620888 & \multicolumn{2}{|c|}{ Adjusted R-squared } & 0.005105 \\
\hline Prob(F-statistics) & 0.205429 & \multicolumn{2}{|c|}{ Sum squared residuals } & 0.002775 \\
\hline Log likelihood & 479.0529 & \multicolumn{2}{|c|}{ S.E. of regression } & 0.004809 \\
\hline Akaike info criterion & -7.820539 & \multicolumn{2}{|c|}{ Hannan-Quinn Criterion } & -7.801868 \\
\hline Schwarz criterion & -7.774571 & \multicolumn{2}{|c|}{ Durbin-Watson stat } & 1.580184 \\
\hline Variable & Coefficient & Std.Error & t-Statistics & Probability \\
\hline Constant & 0.003199 & 0.000490 & 6.523204 & 0.0000 \\
\hline VFED & -0.045309 & 0.035589 & -1.273141 & 0.2054 \\
\hline
\end{tabular}

Heteroskedasticity test result summarized in above tables indicates the error is homoskedastic. 